\title{
Comparison of the Inhibition of Monoamine Oxidase and Butyrylcholinesterase Activities by Infusions from Green Tea and Some Citrus Peels
}

\author{
Ayokunle O. Ademosun and Ganiyu Oboh \\ Functional Foods and Nutraceuticals Unit, Department of Biochemistry, Federal University of Technology, PMB 704, \\ Akure 340001, Nigeria \\ Correspondence should be addressed to Ayokunle O. Ademosun; ayoademosun@yahoo.com
}

Received 31 May 2014; Revised 6 July 2014; Accepted 20 July 2014; Published 5 August 2014

Academic Editor: Paula I. Moreira

Copyright (c) 2014 A. O. Ademosun and G. Oboh. This is an open access article distributed under the Creative Commons Attribution License, which permits unrestricted use, distribution, and reproduction in any medium, provided the original work is properly cited.

\begin{abstract}
This study sought to investigate the effect of infusions from green tea (Camellia sinensis) and some citrus peels [shaddock (Citrus maxima), grapefruit (Citrus paradisi), and orange (Citrus sinensis)] on key enzymes relevant to the management of neurodegenerative conditions [monoamine oxidase $(\mathrm{MAO})$ and butyrylcholinesterase $(\mathrm{BChE})$ ]. The total phenol contents and antioxidant activities as typified by their $2,2^{\prime}$-azino-bis(3-ethylbenzthiazoline-6-sulphonic acid) (ABTS) radicals scavenging abilities, ferric reducing antioxidant properties, and $\mathrm{Fe}^{2+}$ chelating abilities were also investigated. Green tea had the highest total phenol $(43.3 \mathrm{mg} / \mathrm{g})$ and total flavonoid $(16.4 \mathrm{mg} / \mathrm{g})$ contents, when compared to orange [total phenol $(19.6 \mathrm{mg} / \mathrm{g})$, total flavonoid $(6.5 \mathrm{mg} / \mathrm{g})$ ], shaddock [total phenol $(16.3 \mathrm{mg} / \mathrm{g})$, total flavonoid $(5.2 \mathrm{mg} / \mathrm{g})$ ], and grapefruit [total phenol $(17.7 \mathrm{mg} / \mathrm{g})$, total flavonoid $(5.9 \mathrm{mg} / \mathrm{g})]$. Orange $\left(\mathrm{EC}_{50}=1.78 \mathrm{mg} / \mathrm{mL}\right)$ had the highest MAO inhibitory ability, while green tea had the least MAO inhibitory ability $\left(\mathrm{EC}_{50}=2.56 \mathrm{mg} / \mathrm{mL}\right)$. Similarly, green tea had the least $\mathrm{BChE}$ inhibitory ability $\left(\mathrm{EC}_{50}=5.43 \mathrm{mg} / \mathrm{mL}\right)$ when compared to the citrus peels' infusions. However, green tea infusions had the strongest highest ABTS radical scavenging ability, reducing power, and $\mathrm{Fe}^{2+}$ chelating ability. The inhibition of MAO and BChE activities by the green tea and citrus peels infusions could make them good dietary means for the prevention/management of neurodegenerative conditions.
\end{abstract}

\section{Introduction}

Some of the therapeutic targets that have been identified in the management of neurodegenerative conditions include monoamine oxidase (MAO), acetylcholinesterase (AChE), butyrylcholinesterase (BChE), and oxidative stress [1]. The use of MAO inhibitors and their mechanism of action in the management of depression and other neurodegenerative conditions such as Alzheimer's disease (AD) and Parkinson's disease (PD) have been established [2]. Unchecked MAO activity, especially MAO-B, contributes to neurodegeneration leading to Alzheimer's disease development [3]. Furthermore, excessive MAO activity has been linked to increased generation of free radicals in the brain and consequently neuronal damage [3]. Therefore, inhibiting MAO activity is a therapeutic target in the management of $\mathrm{AD}$ and other neurodegenerative conditions.
Reduced cholinergic function in the brain has been shown to result in memory impairment in $\mathrm{AD}$ [4]. Therefore, the use of $\mathrm{AChE}$ and $\mathrm{BChE}$ inhibitors to reduce the hydrolysis of acetylcholine is a therapeutic approach in managing neurodegeneration. However, studies have suggested that the joint inhibition of $\mathrm{AChE}$ and $\mathrm{BChE}$ is preferred to the selective inhibition of $\mathrm{AChE}$ in treating $\mathrm{AD}$ [5]. More so, the activity of AChE has been shown to decline with $\mathrm{AD}$ progression, while $\mathrm{BChE}$ activity increases with the progression of the disease $[6,7]$. Furthermore, efforts aimed at ameliorating oxidative damage have also been shown to be beneficial in the treatment of neurodegenerative conditions. A combination of cholinesterase inhibition and antioxidative abilities is regarded as an effective therapy in management of such conditions [8]. Green tea and citrus peels have been in use in alternative and complementary medicine as a cheap intervention in the management of some degenerative 
conditions and they are consumed in form of infusions in many countries.

The inhibition of AChE activity, inhibition of $\mathrm{Fe}^{2+}$ induced lipid peroxidation, and radical scavenging abilities of aqueous extracts from some citrus peels had been earlier reported [9]. However, this study sought to compare the effect of infusions from green tea (Camellia sinensis) and some citrus peels [shaddock (Citrus maxima), grapefruit (Citrus paradisi), and orange (Citrus sinensis)] on MAO and $\mathrm{BChE}$ (key enzymes linked to neurodegenerative conditions) activities, as well as their iron chelating properties in vitro.

\section{Materials and Methods}

2.1. Sample Collection. Green tea (Camellia sinensis) and some citrus peels shaddock (Citrus maxima), grapefruit (Citrus paradisi), and orange (Citrus sinensis) were collected from the Akure, Southwest, Nigeria. The green tea and peels were sun-dried for 7 days and ground to fine powder.

2.2. Infusion Preparation. The infusions were prepared by soaking the ground samples in boiling water for 5 minutes. The resulting mixture was then filtered and the filtrate was stored in the refrigerator for subsequent analysis.

2.3. Determination of Total Phenol Content. The total phenol content was determined according to the method of Singleton et al. [10]. Briefly, appropriate dilutions of the extracts were oxidized with $2.5 \mathrm{~mL} 10 \%$ Folin-Ciocalteu's reagent (v/v) and neutralized by $2.0 \mathrm{~mL}$ of $7.5 \%$ sodium carbonate. The reaction mixture was incubated for 40 minute at $45^{\circ} \mathrm{C}$ and the absorbance was measured at $765 \mathrm{~nm}$ in the spectrophotometer. The total phenol content was subsequently calculated as gallic acid equivalent (GAE).

2.4. Determination of Total Flavonoid Content. The total flavonoid content was determined using a slightly modified method reported by Meda et al. [11]; briefly $0.5 \mathrm{~mL}$ of appropriately diluted sample was mixed with $0.5 \mathrm{~mL}$ methanol, $50 \mu \mathrm{L} \mathrm{10 \%} \mathrm{AlCl} 3,50 \mu \mathrm{L} 1 \mathrm{M}$ potassium acetate, and $1.4 \mathrm{~mL}$ water and allowed to incubate at room temperature for $30 \mathrm{~min}$. The absorbance of the reaction mixture was subsequently measured at $415 \mathrm{~nm}$; the total flavonoid content was subsequently calculated.

\subsection{Enzyme Inhibition Assays}

2.5.1. Monoamine Oxidase (MAO) Inhibition Assay. The assay of MAO and activity measurement of MAO with different concentrations of infusions was performed as per the methods $[12,13]$, with slight modification. In brief the reaction mixture contained $0.025 \mathrm{M}$ phosphate buffer of $\mathrm{pH}$ 7, $0.0125 \mathrm{M}$ semicarbazide, $10 \mathrm{mM}$ benzylamine ( $\mathrm{pH}$ adjusted to 7 ), and $0.67 \mathrm{mg}$ of enzyme and appropriate dilutions of the infusions in a total reaction volume of $2 \mathrm{~mL}$. After $30 \mathrm{~min}, 1 \mathrm{~mL}$ of acetic acid was added and boiled for $3 \mathrm{~min}$ in boiling water bath followed by centrifugation. The resultant supernatant $(1 \mathrm{~mL})$ was mixed with equal volume of $0.05 \%$ of 2, 4-DNPH and $2.5 \mathrm{~mL}$ of benzene was added after 10 min incubation at room temperature. After separating the benzene layer it was mixed with equal volume of $0.1 \mathrm{~N}$ $\mathrm{NaOH}$. Alkaline layer was decanted and heated at $80^{\circ} \mathrm{C}$ for $10 \mathrm{~min}$. The orange-yellow colour developed was measured at $450 \mathrm{~nm}$.

2.5.2. Butyrylcholinesterase (BChE) Inhibition Assay. Inhibition of BChE was assessed by a modified colorimetric method of Ellman [14]. The BChE activity was determined in a reaction mixture containing $200 \mu \mathrm{L}$ of a solution of BChE $(0.415 \mathrm{U} / \mathrm{mL}$ in $0.1 \mathrm{M}$ phosphate buffer, $\mathrm{pH} 8.0), 100 \mu \mathrm{L}$ of a solution of $5,5^{\prime}$-dithiobis(2-nitrobenzoic) acid (3.3 mM in $0.1 \mathrm{M}$ phosphate-buffered solution, $\mathrm{pH}$ 7.0) containing $\mathrm{NaHCO}_{3}(6 \mathrm{mM})$, juice dilutions $(0-100 \mu \mathrm{L})$, and $500 \mu \mathrm{L}$ of phosphate buffer, $\mathrm{pH}$ 8.0. After incubation for $20 \mathrm{~min}$ at $25^{\circ} \mathrm{C}$, butyrylthiocholine iodide ( $100 \mu \mathrm{L}$ of $0.05 \mathrm{mM}$ solution) was added as the substrate, and BChE activity was determined with an ultraviolet spectrophotometer from the absorbance changes at $412 \mathrm{~nm}$ for $3.0 \mathrm{~min}$ at $25^{\circ} \mathrm{C}$.

\subsection{In Vitro Antioxidant Studies}

2.6.1. $\mathrm{Fe}^{2+}$ Chelation Assay. The $\mathrm{Fe}^{2+}$ chelating ability of the infusions was determined using a modified method of Minotti and Aust [15] with a slight modification by Puntel et al. [16]. Freshly prepared $500 \mu \mathrm{M} \mathrm{FeSO}_{4}(150 \mu \mathrm{L})$ was added to a reaction mixture containing $168 \mu \mathrm{L} 0.1 \mathrm{M}$ Tris- $\mathrm{HCl}(\mathrm{pH}$ 7.4), $218 \mu \mathrm{L}$ saline, and the extracts $(0-25 \mu \mathrm{L})$. The reaction mixture was incubated for $5 \mathrm{~min}$, before the addition of $13 \mu \mathrm{L} 0.25 \%$ 1, 10-phenanthroline (w/v). The absorbance was subsequently measured at $510 \mathrm{~nm}$ in a spectrophotometer. The Fe (II) chelating ability was subsequently calculated.

2.6.2. 2'-Azino-bis(3-ethylbenzthiazoline-6-sulphonic Acid) (ABTS) Radical Scavenging Ability. The ABTS* scavenging ability of the infusions was determined according to the method described by Re et al. [17]. The ABTS* was generated by reacting an $(7 \mathrm{mmol} / \mathrm{L})$ ABTS aqueous solution with $\mathrm{K}_{2} \mathrm{~S}_{2} \mathrm{O}_{8}(2.45 \mathrm{mmol} / \mathrm{L}$, final concentration) in the dark for $16 \mathrm{~h}$ and adjusting the Abs734 $\mathrm{nm}$ to 0.700 with ethanol. $0.2 \mathrm{~mL}$ of appropriate dilution of the extract was added to $2.0 \mathrm{~mL} \mathrm{ABTS} *$ solution and the absorbance were measured at $734 \mathrm{~nm}$ after 15 mins. The Trolox equivalent antioxidant capacity was subsequently calculated.

2.7. Data Analysis. The results of three replicates were pooled and expressed as mean \pm standard deviation (S.D.). Student's $t$-test, one-way analysis of variance (ANOVA), and least significance difference (LSD) were carried out [18]. Significance was accepted at $P \leq 0.05$.

\section{Results}

The results of the total phenol and flavonoid contents of the infusions from green tea and the citrus peels as presented in Table 1 revealed that green tea had the highest total phenol $(43.3 \mathrm{mg} / \mathrm{g})$ and total flavonoid $(16.4 \mathrm{mg} / \mathrm{g})$ content, 


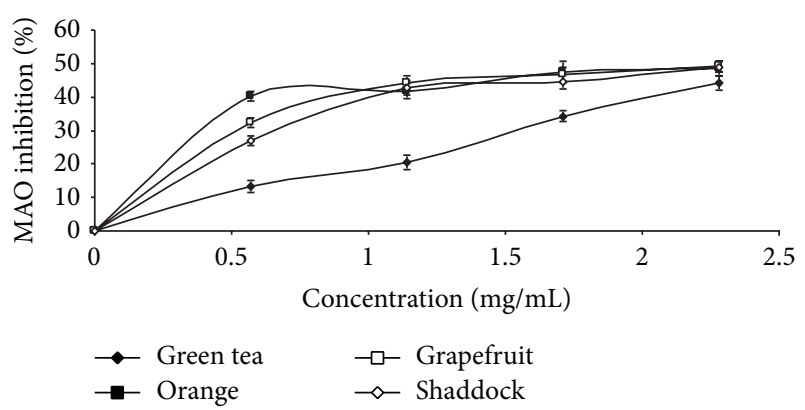

FIGURE 1: Monoamine oxidase inhibitory activity of infusions of green tea and some citrus peels. Values represent means \pm standard deviation of triplicate readings.

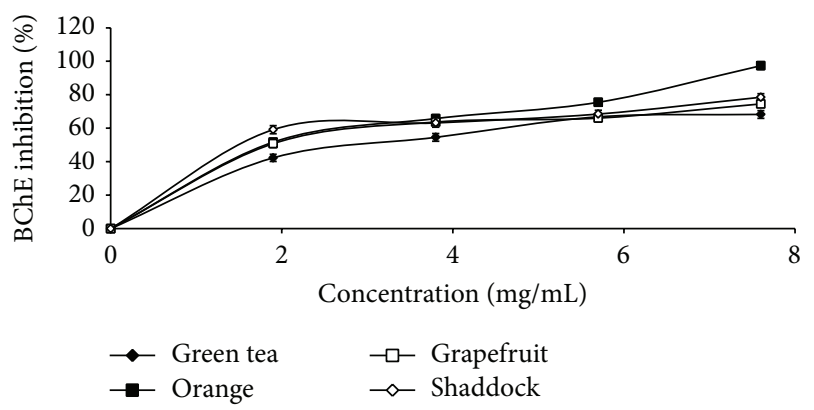

FIGURE 2: Butyrylcholinesterase inhibitory activity of infusions of green tea and some citrus peels. Values represent means \pm standard deviation of triplicate readings.

when compared to orange [total phenol $(19.6 \mathrm{mg} / \mathrm{g})$, total flavonoid $(6.5 \mathrm{mg} / \mathrm{g})$ ], shaddock [total phenol $(16.3 \mathrm{mg} / \mathrm{g})$, total flavonoid $(5.2 \mathrm{mg} / \mathrm{g})]$, and grapefruit [total phenol $(17.7 \mathrm{mg} / \mathrm{g})$, total flavonoid $(5.9 \mathrm{mg} / \mathrm{g})]$. The effects of the infusions on monoamine oxidase and butyrylcholinesterase activities are presented in Figures 1 and 2, respectively, and the $\mathrm{EC}_{50}$ values in Table 2 . The infusions inhibited the enzymes' activities in a dose-dependent manner. However, orange $\left(\mathrm{EC}_{50}=1.78 \mathrm{mg} / \mathrm{mL}\right)$ had the highest MAO inhibitory ability, while green tea had the least MAO inhibitory ability $\left(\mathrm{EC}_{50}\right.$ $=2.56 \mathrm{mg} / \mathrm{mL}$ ). Similarly, the BChE inhibitory abilities of the infusions revealed that green tea had the least inhibitory ability $\left(\mathrm{EC}_{50}=5.43 \mathrm{mg} / \mathrm{mL}\right)$ when compared to the other infusions [orange $\left(\mathrm{EC}_{50}=3.61 \mathrm{mg} / \mathrm{mL}\right)$; shaddock $\left(\mathrm{EC}_{50}\right.$ $=4.42 \mathrm{mg} / \mathrm{mL}) ;$ grapefruit $\left.\left(\mathrm{EC}_{50}=4.20 \mathrm{mg} / \mathrm{mL}\right)\right]$. Figure 3 and Table 2 revealed that infusions from green tea $\left(\mathrm{EC}_{50}\right.$ $=0.63 \mathrm{mg} / \mathrm{mL}$ ) had the highest $\mathrm{Fe}^{2+}$ chelating ability in comparison to the citrus peels' infusions [orange $\left(\mathrm{EC}_{50}\right.$ $=0.72 \mathrm{mg} / \mathrm{mL}) ;$ grapefruit $\left(\mathrm{EC}_{50}=0.81 \mathrm{mg} / \mathrm{mL}\right)$; shaddock $\left.\left(\mathrm{EC}_{50}=0.82 \mathrm{mg} / \mathrm{mL}\right)\right]$. Furthermore, the ABTS radical scavenging abilities of the infusions reported as Trolox equivalent (Figure 4) revealed that green tea $(9.71 \mathrm{mmol} / \mathrm{g})$ had the highest ABTS radical scavenging ability, while grapefruit $(4.13 \mathrm{mmol} / \mathrm{g})$ and shaddock $(3.99 \mathrm{mmol} / \mathrm{g})$ had the least.

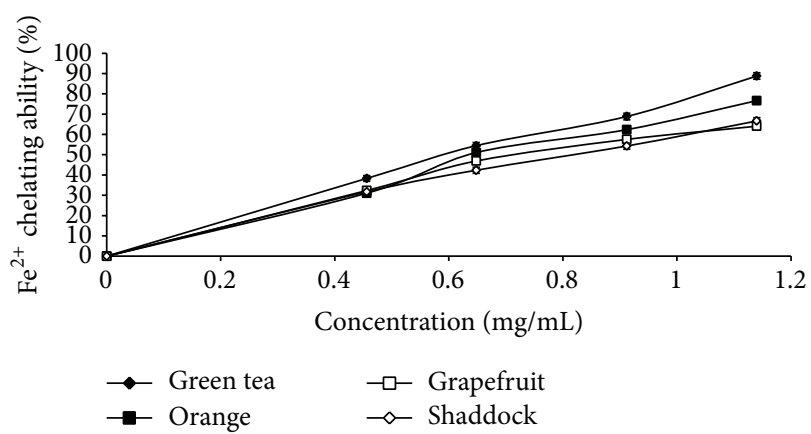

Figure 3: $\mathrm{Fe}^{2+}$ chelating abilities of infusions of green tea and some citrus peels. Values represent means \pm standard deviation of triplicate readings.

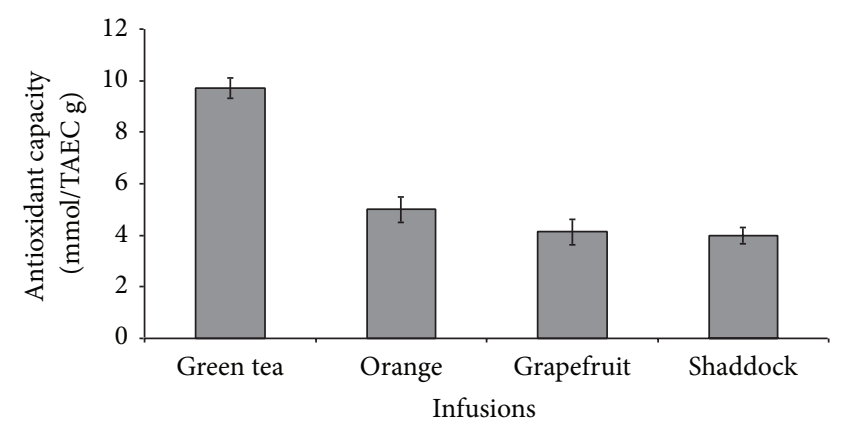

FIGURE 4: ABTS* scavenging ability of infusions of green tea and some citrus peels.

TABLE 1: Total phenolic and flavonoid contents of infusions of green tea and some citrus peels.

\begin{tabular}{lcc}
\hline Sample & $\begin{array}{c}\text { Total phenol } \\
(\mathrm{mg} \mathrm{GAE} / \mathrm{g})\end{array}$ & $\begin{array}{c}\text { Total flavonoid } \\
(\mathrm{mg} \mathrm{QE} / \mathrm{g})\end{array}$ \\
\hline Green tea & $43.3 \pm 2.3^{\mathrm{a}}$ & $16.0 \pm 2.1^{\mathrm{a}}$ \\
Orange & $19.6 \pm 1.1^{\mathrm{b}}$ & $6.5 \pm 1.2^{\mathrm{b}}$ \\
Shaddock & $16.3 \pm 1.1^{\mathrm{b}}$ & $5.2 \pm 0.9^{\mathrm{b}}$ \\
Grapefruit & $17.7 \pm 1.2^{\mathrm{b}}$ & $5.9 \pm 0.8^{\mathrm{b}}$ \\
\hline
\end{tabular}

Values represent means of triplicate. Values with the same alphabet along the same column are not significantly different $(P>0.05)$.

$\mathrm{GAE}$, gallic acid equivalents; $\mathrm{QE}$, quercetin equivalents.

\section{Discussion}

The inhibition of monoamine oxidase and BChE by the infusions used in this study suggests their potential use in the management of neurodegenerative conditions such as $\mathrm{AD}$ and PD. This study showed that infusions of grapefruit, orange, and shaddock peels had higher inhibitory effects on these enzymes than green tea infusions. The therapeutic importance of MAO inhibition by the infusions is buttressed by the fact that there is a decrease in the levels of monoamine neurotransmitters (dopamine, serotonin, and norepinephrine) and an increase in the activity of MAO in the brain tissues of $\mathrm{AD}$ patients $[3,19]$. Therefore, the inhibition of MAO is central in increasing the levels of these neurotransmitters in the brain. More so, MAO inhibitors have 
TABLE 2: $\mathrm{EC}_{50}$ values of inhibition of monoamine oxidase, butyrylcholinesterase, and $\mathrm{Fe}^{2+}$ chelating abilities of green tea and some citrus peels' infusions.

\begin{tabular}{lcccc}
\hline & Green tea & Orange & Grapefruit & Shaddock \\
\hline MAO inhibition & $2.56 \pm 0.09^{\mathrm{a}}$ & $1.78 \pm 0.11^{\mathrm{b}}$ & $2.00 \pm 0.08^{\mathrm{c}}$ & $1.93 \pm 0.06^{\mathrm{c}}$ \\
$\mathrm{BChE}$ inhibition & $5.43 \pm 0.10^{\mathrm{a}}$ & $3.61 \pm 0.06^{\mathrm{b}}$ & $4.20 \pm 0.09^{\mathrm{c}}$ & $4.42 \pm 0.07^{\mathrm{d}}$ \\
$\mathrm{Fe}^{2+}$ chelation & $0.63 \pm 0.11^{\mathrm{a}}$ & $0.72 \pm 0.09^{\mathrm{b}}$ & $0.81 \pm 0.07^{\mathrm{c}}$ & $0.82 \pm 0.09^{\mathrm{c}}$ \\
\hline
\end{tabular}

Values represent means of triplicate. Values with the same alphabet along the same row are not significantly different $(P>0.05)$.

been shown from previous studies to reduce the production of reactive oxygen species [3]. The MAO inhibition by the infusions could be linked to the phenolic composition as flavonoid derivatives have been shown to be MAO inhibitors due to their structural similarity to synthetic inhibitors [20]. The cholinesterases are important therapeutic targets in the management of $\mathrm{AD}[7]$. The $\mathrm{AChE}$ inhibitory properties of citrus peel aqueous extracts had been earlier reported by the authors [9]. This study showed that infusions from citrus peels had a higher BChE inhibitory effect than green tea infusions. $\mathrm{BChE}$ inhibition is very important in $\mathrm{AD}$ management as the concentration of $\mathrm{BChE}$ rises with the progression of the degenerative condition $[5,6]$. Green tea and citrus peels are rich in phenolic compounds, especially flavonoids which have also been shown to possess anticholinesterase properties $[21,22]$. It has also been shown that there exists a structural similarity between natural polyphenolic compounds and established cholinesterase inhibitors in terms of molecular weight, phenolic rings, and hydrophobic component [23].

MAO activity has been shown to result in higher free radicals generation [24]. Similarly, previous studies have shown an increase in MAO activity and iron in the neurodegenerative processes leading to Alzheimer's disease and Parkinson's disease [1]. The neuroprotective effects of MAO inhibitors had also been linked to their ability to inhibit the formation of $\mathrm{H}_{2} \mathrm{O}_{2}$ and $\mathrm{NH}_{3}$, which are harmful products of amine degradation [25]. Therefore, the radical scavenging abilities and iron chelating properties of the infusions further confirm their potentials as dietary means for the management of neurodegenerative conditions. The antioxidant activities of the green tea and citrus peels' infusions were studied using different in vitro methods due to the complex composition of natural substances. The radicals [1,1-diphenyl-2 picrylhydrazyl (DPPH) and hydroxyl (OH)] scavenging abilities of aqueous extracts of the citrus peels used in this study had been earlier reported by the authors [9]. However, in this study the radical scavenging abilities of infusions from green tea and some citrus peels were studied using a more stable nitrogen-centred radical species (ABTS*) [17]. The results revealed that green tea had the highest ABTS* scavenging ability compared to infusions from the peels.

The $\mathrm{Fe}^{2+}$ chelating abilities of the infusions as shown in this study could be of therapeutic benefit in AD management as iron chelators have demonstrated beneficial effects in $\mathrm{AD}$ patients [26] by slowing the progression of the disease. Iron has been shown to accumulate in the brain of $\mathrm{AD}$ patients [27] and generates radicals through the Fenton reaction [28]. Synthetic iron chelators have the disadvantage of high toxicity and difficulty crossing the blood brain barrier
[29]. However, the infusions used in this study are rich in phenolic compounds which are iron chelators and can cross the blood brain barrier $[1,30]$. Other studies have also suggested that MAO inhibitors and iron chelators would be effective in the management of neurodegenerative conditions [31]. Therefore, novel compounds which are combined iron chelators and MAO inhibitors have been developed. The bifunctional ability of the infusions used in this study to inhibit MAO and chelate $\mathrm{Fe}^{2+}$ could be part of the mechanism by which green tea and citrus peels could manage or prevent neurodegeneration.

The high total phenolic and flavonoid contents of the green tea and citrus peels' infusions agree with earlier research articles $[32,33]$. Furthermore, the total phenolics and flavonoids contents of the citrus peels varied between the citrus species tested (shaddock, grapefruit, and orange). The high total phenolics content of the peels agreed with earlier reports on the phenolics content of some citrus peels. These variations could be due to factors such as the genetic potential of individual species for biosynthesis of secondary metabolites such as polyphenols [34].

\section{Conclusion}

The antioxidant properties and inhibition of $\mathrm{MAO}$ and $\mathrm{BChE}$ by the green tea and citrus peels infusions make them good dietary means for the management of neurodegenerative conditions. However, further in vivo experiments and clinical trials are recommended.

\section{Conflict of Interests}

The authors declare that there is no conflict of interests regarding the publication of this paper.

\section{References}

[1] M. B. H. Youdim, D. Edmondson, and K. F. Tipton, "The therapeutic potential of monoamine oxidase inhibitors," Nature Reviews Neuroscience, vol. 7, no. 4, pp. 295-309, 2006.

[2] P. Riederer, E. Sofic, W. D. Rausch et al., "Transition metals, ferritin, glutathione, and ascorbic acid in parkinsonian brains," Journal of Neurochemistry, vol. 52, no. 2, pp. 515-520, 1989.

[3] T. Thomas, "Monoamine oxidase-B inhibitors in the treatment of Alzheimers disease," Neurobiology of Aging, vol. 21, no. 2, pp. 343-348, 2000.

[4] P. K. Mukherjee, V. Kumar, M. Mal, and P. J. Houghton, "Acetylcholinesterase inhibitors from plants," Phytomedicine, vol. 14, no. 4, pp. 289-300, 2007. 
[5] R. M. Lane, S. G. Potkin, and A. Enz, "Targeting acetylcholinesterase and butyrylcholinesterase in dementia," International Journal of Neuropsychopharmacology, vol. 9, no. 1, pp. 101124, 2006.

[6] M. I. Fernández-Bachiller, C. Pérez, L. Monjas, J. Rademann, and M. I. Rodríguez-Franco, "New tacrine-4-oxo-4Hchromene hybrids as multifunctional agents for the treatment of Alzheimer's disease, with cholinergic, antioxidant, and $\beta$ amyloid-reducing properties," Journal of Medicinal Chemistry, vol. 55, no. 3, pp. 1303-1317, 2012.

[7] C. S. Passos, C. A. Simões-Pires, A. Nurisso et al., "Indole alkaloids of Psychotria as multifunctional cholinesterases and monoamine oxidases inhibitors," Phytochemistry, vol. 86, pp. 820, 2013.

[8] S. Vladimir-Kneevic, B. Blaekovic, M. Kindl, J. Vladic, A. D. Lower-Nedza, and A. H. Brantner, "Acetylcholinesterase inhibitory, antioxidant and phytochemical properties of selected medicinal plants of the Lamiaceae family," Molecules, vol. 19, pp. 767-782, 2014.

[9] A. O. Ademosun and G. Oboh, "Anticholinesterase and antioxidative properties of water-extractable phytochemicals from some citrus peels," Journal of Basic and Clinical Physiology and Pharmacology, vol. 25, no. 2, pp. 199-204, 2014.

[10] V. L. Singleton, R. Orthofer, and R. M. Lamuela-Raventós, "Analysis of total phenols and other oxidation substrates and antioxidants by means of folin-ciocalteu reagent," Methods in Enzymology, vol. 299, pp. 152-178, 1998.

[11] A. Meda, C. E. Lamien, M. Romito, J. Millogo, and O. G. Nacoulma, "Determination of the total phenolic, flavonoid and proline contents in Burkina Fasan honey, as well as their radical scavenging activity," Food Chemistry, vol. 91, no. 3, pp. 571-577, 2005.

[12] A. L. Green and T. M. Haughton, "A colorimetric method for the estimation of monoamine oxidase," Biochemical Journal, vol. 78, pp. 172-176, 1961.

[13] W. Turski, E. Turska, and M. Gross Bellard, "Modification of the spectrophotometric method of the determination of monoamine oxidase," Enzyme, vol. 14, no. 4, pp. 211-220, 1973.

[14] G. L. Ellman, K. D. Courtney, V. Andres Jr., and R. M. Featherstone, "A new and rapid colorimetric determination of acetylcholinesterase activity," Biochemical Pharmacology, vol. 7, no. 2, pp. 88-95, 1961.

[15] G. Minotti and S. D. Aust, "An investigation into thee mechanism of citrate-Fe2+-dependent lipid peroxidation," Free Radical Biology and Medicine, vol. 3, no. 6, pp. 379-387, 1987.

[16] R. L. Puntel, C. W. Nogueira, and J. B. T. Rocha, "Krebs cycle intermediates modulate thiobarbituric acid reactive species (TBARS) production in rat brain in vitro," Neurochemical Research, vol. 30, no. 2, pp. 225-235, 2005.

[17] R. Re, N. Pellegrini, A. Proteggente, A. Pannala, M. Yang, and C. Rice-Evans, "Antioxidant activity applying an improved ABTS radical cation decolorization assay," Free Radical Biology \& Medicine, vol. 26, no. 9-10, pp. 1231-1237, 1999.

[18] J. H. Zar, Biostatistical Analysis, Prentice Hall, Bergen, NJ, USA, 1984.

[19] J. Olfsson, R. Adolfsson, C. G. Gottfries, and B. E. Roos, "Changes in the brain catecholamines in patients with dementia of Alzheimer type," The British Journal of Psychiatry, vol. 135, no. 3, pp. 216-223, 1979.

[20] H. Benamar, W. Rached, A. Derdour, and A. Marouf, "Screening of Algerian medicinal plants for acetylcholinesterase inhibitory activity," Journal of Biological Sciences, vol. 10, no. 1, pp. 1-9, 2010.
[21] D. Shahwar, S. U. Rehman, and M. A. Raza, "Acetyl cholinesterase inhibition potential and antioxidant activities of ferulic acid isolated from Impatiens bicolor Linn.", Journal of Medicinal Plants Research, vol. 4, no. 3, pp. 260-266, 2010.

[22] D. Szwajgier and K. Borowiec, "Phenolic acids from malt are efficient acetylcholinesterase and butyrylcholinesterase inhibitors," Journal of the Institute of Brewing, vol. 118, no. 1, pp. 40-48, 2012.

[23] M. Nebbioso, A. Pascarella, C. Cavallotti, and N. Pescosolido, "Monoamine oxidase enzymes and oxidative stress in the rat optic nerve: age-related changes," International Journal of Experimental Pathology, vol. 93, no. 6, pp. 401-405, 2012.

[24] G. B. Baker, D. Matveychuk, E. M. MacKenzie, S. M. Dursun, and D. D. Mousseau, "Monoamine oxidase inhibitors and neuroprotective mechanisms," Bulletin of Clinical Psychopharmacology, vol. 22, no. 4, pp. 293-296, 2012.

[25] H. Bayır, P. M. Kochanek, and V. E. Kagan, "Oxidative stress in immature brain after traumatic brain injury," Developmental Neuroscience, vol. 28, no. 4-5, pp. 420-431, 2006.

[26] G. Liu, P. Men, G. Perry, and M. A. Smith, "Nanoparticle and iron chelators as a potential novel Alzheimer therapy," Methods in Molecular Biology, vol. 610, pp. 123-144, 2010.

[27] R. R. Crichton, D. T. Dexter, and R. J. Ward, "Brain iron metabolism and its perturbation in neurological diseases," Journal of Neural Transmission, vol. 118, no. 3, pp. 301-314, 2011.

[28] W. R. Markesbery and J. M. Carney, "Oxidative alterations in Alzheimer's disease," Brain Pathology, vol. 9, no. 1, pp. 133-146, 1999.

[29] R. C. Hider, J. B. Porter, and S. Singh, “The design of therapeutically useful iron chelators," in The Development of Iron Chelators for Clinical Use, R. J. Bergeron and G. M. Brittenham, Eds., pp. 353-371, CRC Press, Boca Raton, Fla, USA, 1994.

[30] M. M. Abd El Mohsen, G. Kuhnle, A. R. Rechner et al., "Uptake and metabolism of epicatechin and its access to the brain after oral ingestion," Free Radical Biology and Medicine, vol. 33, no. 12, pp. 1693-1702, 2002.

[31] S. Gal, H. Zheng, M. Fridkin, and M. B. H. Youdim, "Novel multifunctional neuroprotective iron chelator-monoamine oxidase inhibitor drugs for neurodegenerative diseases. In vivo selective brain monoamine oxidase inhibition and prevention of MPTP-induced striatal dopamine depletion," Journal of Neurochemistry, vol. 95, no. 1, pp. 79-88, 2005.

[32] C. Anesini, G. E. Ferraro, and R. Filip, "Total polyphenol content and antioxidant capacity of commercially available tea (Camellia sinensis) in Argentina," Journal of Agricultural and Food Chemistry, vol. 56, no. 19, pp. 9225-9229, 2008.

[33] K. Ghasemi, Y. Ghasemi, and M. A. Ebrahimzadeh, "Antioxidant activity, phenol and flavonoid contents of 13 citrus species peels and tissues," Pakistan Journal of Pharmaceutical Sciences, vol. 22, no. 3, pp. 277-281, 2009.

[34] S. Kallithraka, A. A. Mohdaly, D. P. Makris, and P. Kefalas, "Determination of major anthocyanin pigments in Hellenic native grape varieties (Vitis vinifera sp.): Association with antiradical activity," Journal of Food Composition and Analysis, vol. 18, no. 5, pp. 375-386, 2005. 


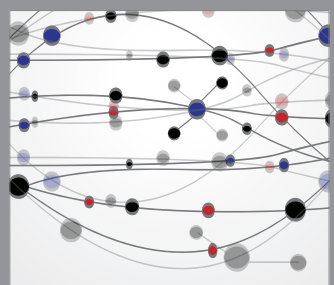

The Scientific World Journal
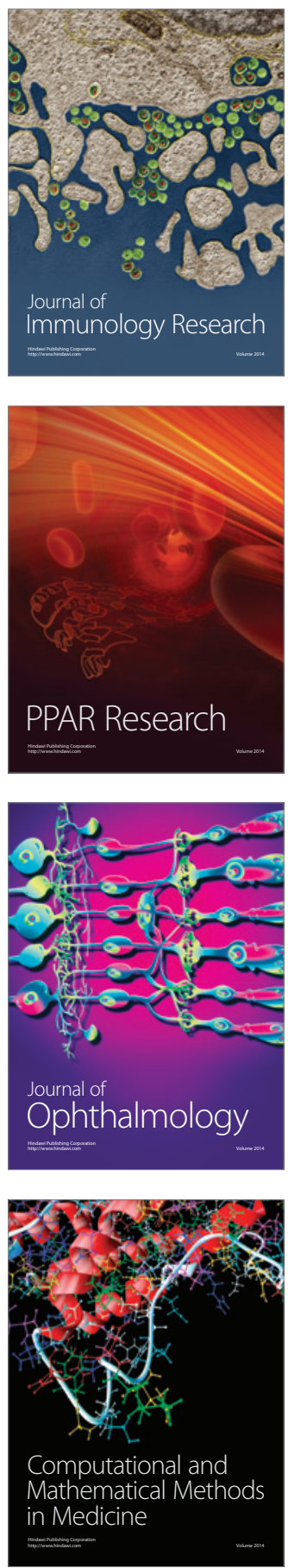

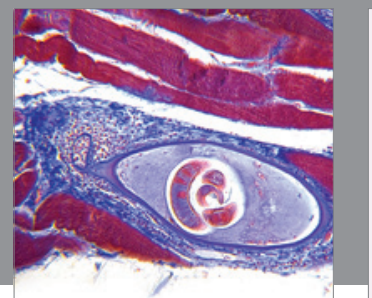

Gastroenterology

Research and Practice
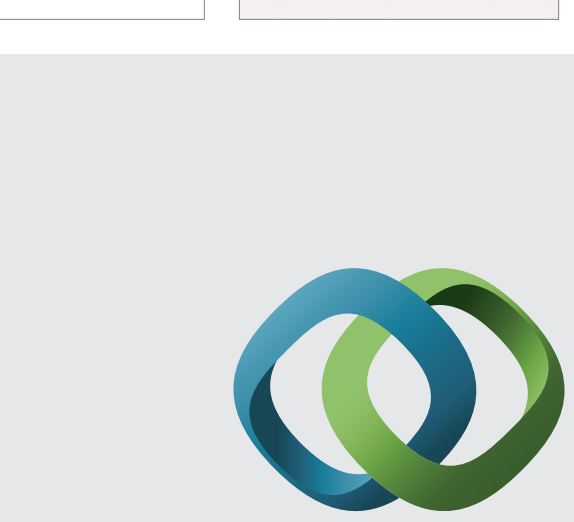

\section{Hindawi}

Submit your manuscripts at

http://www.hindawi.com
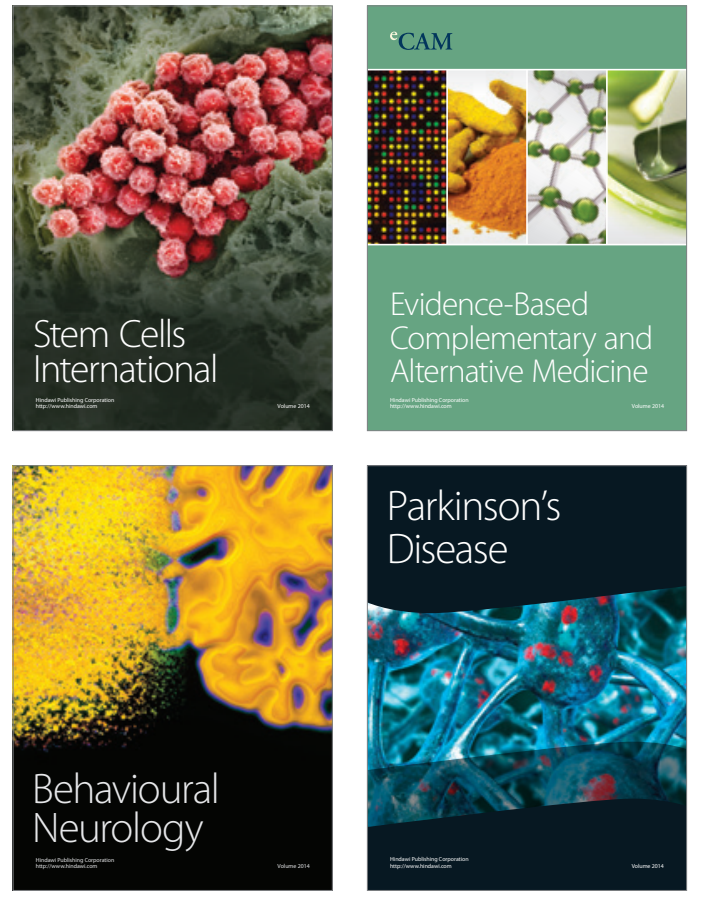
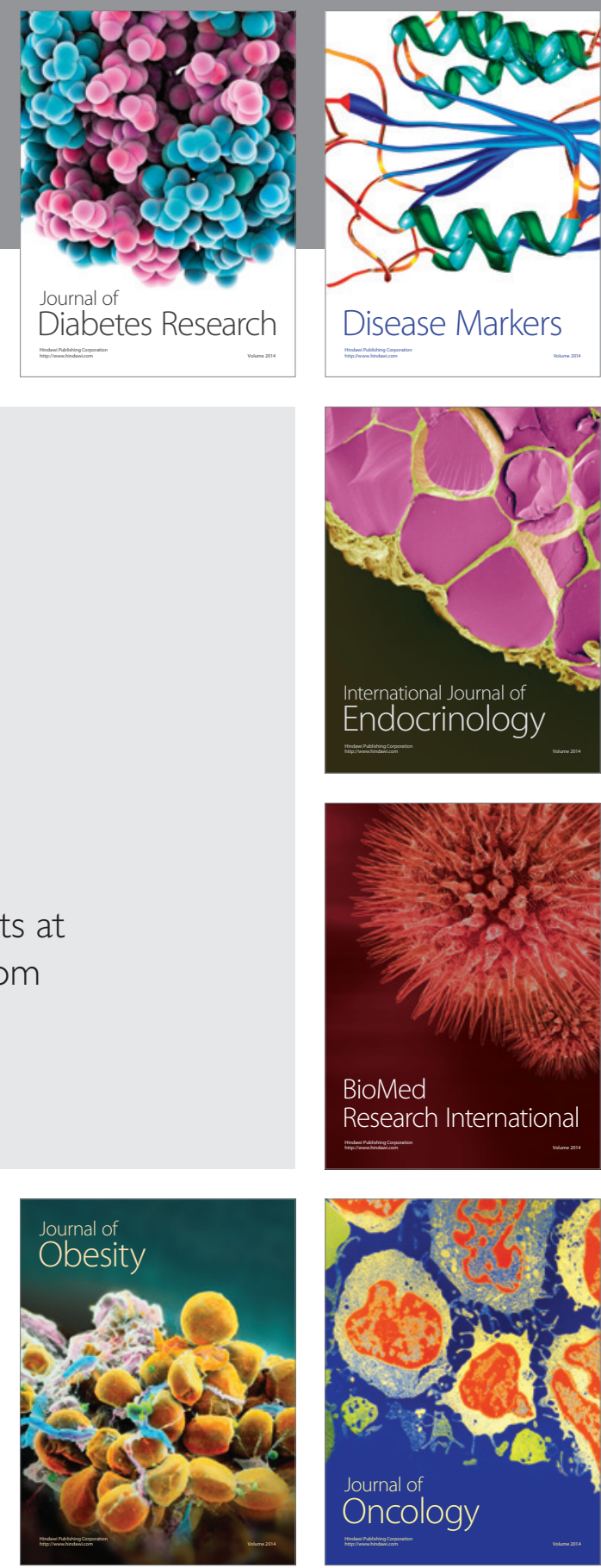

Disease Markers
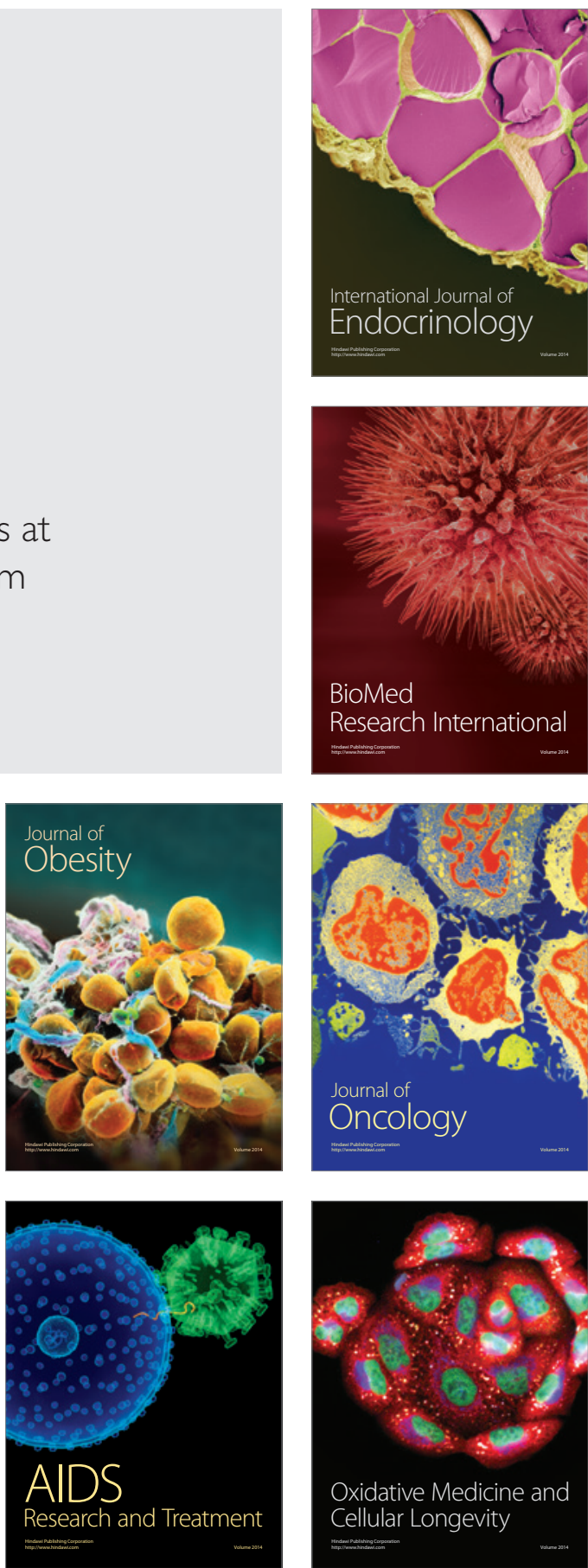